\title{
A 5-year study (2014-2018) of the relationship between coastal phytoplankton abundance and intertidal barnacle size along the Atlantic Canadian coast
}

\author{
Ricardo A Scrosati ${ }^{\text {Corresp., }}{ }^{\text {, Julius A Ellrich }}$ \\ 1 Department of Biology, St. Francis Xavier University, Antigonish, Nova Scotia, Canada \\ Corresponding Author: Ricardo A Scrosati \\ Email address: rscrosat@stfx.ca
}

Benthic-pelagic coupling refers to the ecological relationships between benthic and pelagic environments. Studying such links is particularly useful to understand biological variation in intertidal organisms along marine coasts. Filter-feeding invertebrates are ecologically important on marine rocky shores, so they have often been used to investigate benthic-pelagic coupling. Most studies, however, have been conducted on eastern ocean boundaries. To evaluate benthic-pelagic coupling on a western ocean boundary, we conducted a 5-year study spanning $415 \mathrm{~km}$ of the Atlantic coast of Nova Scotia (Canada). We hypothesized that the summer size of intertidal barnacles (Semibalanus balanoides) recruited in the preceding spring would be positively related to the nearshore abundance (biomass) of phytoplankton, as phytoplankton constitutes food for the nauplius larvae and benthic stages of barnacles. Every year between 2014 and 2018, we measured summer barnacle size in clearings created before spring recruitment on the rocky substrate at eight wave-exposed locations along this coast. We then examined the annual relationships between barnacle size and chlorophyll-a concentration (Chl-a), a proxy for phytoplankton biomass. For every year and location, we used satellite data to calculate Chl-a averages for a period ranging from the early spring (when most barnacle larvae were in the water) to the summer (when barnacle size was measured after weeks of growth following spring benthic recruitment). The relationships were always positive, Chl-a explaining nearly half, or more, of the variation in barnacle size in four of the five studied years. These are remarkable results because they were based on a relatively limited number of locations (which often curtails statistical power) and point to the relevance of pelagic food supply to explain variation in intertidal barnacle size along this western ocean boundary coast. 
1 A 5-year study (2014-2018) of the relationship between coastal phytoplankton 2 abundance and intertidal barnacle size along the Atlantic Canadian coast

* Corresponding author. Email: rscrosat@stfx.ca. Phone:+1-902-867-5289. 


\section{ABSTRACT}

Benthic-pelagic coupling refers to the ecological relationships between benthic and pelagic environments. Studying such links is particularly useful to understand biological variation in intertidal organisms along marine coasts. Filter-feeding invertebrates are ecologically important on marine rocky shores, so they have often been used to investigate benthic-pelagic coupling. Most studies, however, have been conducted on eastern ocean boundaries. To evaluate benthicpelagic coupling on a western ocean boundary, we conducted a 5 -year study spanning $415 \mathrm{~km}$ of the Atlantic coast of Nova Scotia (Canada). We hypothesized that the summer size of intertidal barnacles (Semibalanus balanoides) recruited in the preceding spring would be positively related to the nearshore abundance (biomass) of phytoplankton, as phytoplankton constitutes food for the nauplius larvae and benthic stages of barnacles. Every year between 2014 and 2018, we measured summer barnacle size in clearings created before spring recruitment on the rocky substrate at eight wave-exposed locations along this coast. We then examined the annual relationships between barnacle size and chlorophyll- $a$ concentration (Chl- $a$ ), a proxy for phytoplankton biomass. For every year and location, we used satellite data to calculate Chl- $a$ averages for a period ranging from the early spring (when most barnacle larvae were in the water) to the summer (when barnacle size was measured after weeks of growth following spring benthic recruitment). The relationships were always positive, Chl- $a$ explaining nearly half, or more, of the variation in barnacle size in four of the five studied years. These are remarkable results because they were based on a relatively limited number of locations (which often curtails statistical power) and point to the relevance of pelagic food supply to explain variation in intertidal barnacle size along this western ocean boundary coast. 
Benthic-pelagic coupling refers to the ecological relationships that exist between benthic and pelagic environments (Griffiths et al., 2017). Recognition of such links has particularly facilitated progress in the field of intertidal ecology. For example, understanding how pelagic

35

food supply and oceanographic features vary along coastlines frequently helps to predict, directly or indirectly, alongshore properties of intertidal species. Such studies, however, have overwhelmingly been conducted on eastern ocean boundaries (Navarrete et al., 2005; Blanchette et al., 2008; Menge \& Menge, 2013; Salant \& Shanks, 2018).

For western ocean boundaries, a question needing more research remains to what extent alongshore variation in intertidal species traits can be inferred from nearshore pelagic variables. On the SW Atlantic coast, for example, the recruitment of intertidal filter-feeders (barnacles and mussels) was recently found related to the abundance of phytoplankton (their main food source), wave exposure, and seawater temperature (Arribas et al., 2014; Mazzuco et al., 2015). On the NW Atlantic coast, surveys in the Gulf of Maine suggested that intertidal filter-feeder recruitment might be influenced by currents affecting larval supply (Bryson, Trussell \& Ewanchuk, 2014). Larger-scale NW Atlantic surveys including sites on Canadian and American shores have found links between coastal phytoplankton abundance and intertidal barnacle recruitment (Cole et al., 2011) and between thermal stress during low tides and intertidal mussel abundance (Tam \& Scrosati, 2011).

The Atlantic Canadian coast in Nova Scotia is well suited to study benthic-pelagic coupling, as it runs for some hundreds of $\mathrm{km}$ facing the open ocean. A study in 2014 revealed that the recruitment of intertidal barnacles and mussels in wave-exposed locations along this coast was positively related to pelagic food supply and, to a lesser degree, seawater temperature. In turn, 
54 recruitment of these filter-feeders was related to their abundance later in the year and, ultimately,

55 to the abundance of their main predators (dogwhelks), suggesting bottom-up community

56 regulation (Scrosati \& Ellrich, 2018). While filter-feeder recruitment may predict predator

57 abundance and even facilitation on other organisms (Menge, 1976), filter-feeder size is another

58 important aspect of bottom-up regulation, as larger sizes represent more food for higher trophic

59 levels (Dunkin \& Hughes, 1984; Carroll \& Wethey, 1990). Therefore, in this paper, we focus on

60 barnacle size. Using field data for five consecutive years (2014-2018), we test the hypothesis

61 that phytoplankton abundance (biomass) is positively related to intertidal barnacle size along this

62 coast.

63

64

65

66

67

68

69

70

71

72

73

74

75

76

\section{MATERIALS AND METHODS}

From 2014 to 2018, we collected data at eight intertidal locations spanning $415 \mathrm{~km}$ of the Atlantic coast of Nova Scotia (Fig. 1). For ease of interpretation, these locations are referred to as L1 to L8, from north to south (their names and coordinates are given in Table 1). They all have stable bedrock as substrate and are wave-exposed, as they face the open ocean directly. Daily maximum water velocity (an indication of wave exposure) measured in exposed intertidal habitats along this coast ranges between 6-12 $\mathrm{m} \mathrm{s}^{-1}$ (Hunt \& Scheibling, 2001; Scrosati \& Heaven, 2007; Ellrich \& Scrosati, 2017). Using wave-exposed intertidal habitats to study benthic-pelagic coupling is particularly fitting because such places face the open ocean, which facilitates the identification of pelagic influences.

We measured the size of Semibalanus balanoides, which is the only intertidal barnacle species on this coast. For each location, we considered the intertidal range to be the vertical distance between chart datum ( $0 \mathrm{~m}$ in elevation, or lowest normal tide in Canada) and the highest elevation where sessile perennial organisms (coincidentally, S. balanoides) occurred on the

Peer] reviewing PDF | (2019:01:34119:1:1:NEW 7 Mar 2019) 
77 substrate outside of crevices (Scrosati \& Heaven, 2007). We divided the intertidal range by three

78 and measured barnacle size just above the bottom boundary of the upper third of the intertidal range. As tidal amplitude increases from $1.8 \mathrm{~m}$ in L1 to $2.4 \mathrm{~m}$ in L8 (Tide-Forecast, 2019), this

80 method allowed us to measure barnacle size along the coast at comparable elevations in terms of 81 exposure to aerial conditions during low tides.

In Atlantic Canada, Semibalanus balanoides mates in autumn, broods in winter, and releases pelagic larvae in spring (Bousfield, 1954; Crisp, 1968; Bouchard \& Aiken, 2012). Larvae settle in intertidal habitats and metamorphose into benthic recruits during May and June, which is thus considered to be the recruitment season (Ellrich, Scrosati \& Molis, 2015). To measure barnacle size unaffected by other sessile species (Beermann et al., 2013), we made clearings (100-cm² quadrats) of the substrate in late April of each year along the same intertidal elevation (see above) at each location. Table 2 gives the number of quadrats with barnacle size data for each location and year. Different quadrats were cleared each year by removing all pre-existing organisms from the substrate using a chisel and a metallic mesh scourer. We measured the size 91 of the barnacles recruited therein as they looked in summer after growth (Table 2, Fig. 2). We 92 determined barnacle size as the basal shell diameter measured along a straight line passing 93 through the middle of the rostrum and the carina (Chan et al., 2006). To avoid influences of 94 intraspecific crowding (Bertness, 1989) on our size data, we only measured barnacles that were 95 not in contact with any neighbouring barnacles. Such organisms were common because, in 96 summer, barnacles constituted almost the only macroscopic species in the quadrats and their 97 density was not particularly high (Fig. 2). We measured size for a maximum of 10 such barnacles 98 per quadrat (all barnacles if there were 10 or less in a quadrat and a random selection of 10 if 99 there were more than 10 in a quadrat). For data analyses, we first calculated mean barnacle size 
100 for each quadrat and, then, averaged the corresponding quadrat means to generate a value of

101 mean barnacle size per location and year.

102 To describe phytoplankton abundance, we used MODIS-Aqua satellite data on the

103 concentration of chlorophyll- $a$ in seawater (Chl- $a$, hereafter) for the 4-km-X-4-km cells that

104 include our eight locations (NASA, 2019a). The coordinates of each cell are stated in Table 1.

105 Satellite Chl- $a$ data are often used in intertidal ecology (Navarrete et al., 2005; Burrows et al.,

106 2010; Arribas et al., 2014; Mazzuco et al., 2015; Lara et al., 2016) and are especially useful

107 when studying hundreds of $\mathrm{km}$ of coastline for which in-situ phytoplankton data are lacking

108 (Legaard \& Thomas, 2006). For this study, satellite data should be appropriate because

109 neighbouring locations are considerably more distant from one another than the data cell size

110 (Fig. 1). To retrieve the Chl- $a$ data, we first obtained mapped Chl- $a$ data from the OceanColor

111 database $(N A S A, 2019 a)$. From these mapped data, we extracted the Chl- $a$ values for our

112 locations using the pixel extraction function of SeaDAS $(N A S A, 2019 b)$ and the coordinates of

113 our locations (Table 1). For each location and year, we calculated the mean of all of the daily

114 Chl- $a$ values that were available from the beginning of April to the date when we measured

115 barnacle size in summer (Table 2). Although barnacle recruitment occurs in May and June, we

116 considered April Chl- $a$ because of its possible effects on larval condition ultimately influencing

117 benthic growth (Barnes, 1956; Emlet \& Sadro, 2006). Specifically, the nauplius larvae of $S$.

118 balanoides feed for 5-6 weeks in coastal waters before reaching the settling cyprid stage

119 (Bousfield, 1954; Drouin, Bourget \& Tremblay, 2002), and a recent study in our region

120 concluded that most of the larvae that result in recruits are likely in the water in April (Scrosati

$121 \&$ Ellrich, 2016). The Chl- $a$ values between May and the summer dates when we measured

122 barnacle size were used to represent pelagic food supply for the growing recruits. 
123 For each year, we investigated the relationship between phytoplankton abundance and

124 barnacle size by evaluating Pearson's correlation between the location means of Chl- $a$ and size.

125 As our hypothesis was directional (a positive association between both variables), we performed

126 one-tailed tests of significance (Quinn \& Keough, 2002). We also calculated the coefficient of

127 determination for each year to evaluate the amount of variation in barnacle size that was

128 statistically explained by Chl-a. We did the analyses with R version 3.5.1 (R Core Team, 2018).

129 The data used for this study are available in figshare (doi: 10.6084/m9.figshare.7212446).

$130 \quad$ RESULTS

131 The observed relationships between Chl- $a$ and barnacle size were always positive. The

132 correlation coefficient was significant for 2014, 2016, and 2018 under a significance level of

1330.05 and for 2015 under a less conservative significance level of 0.10 (Fig. 3). For 2017, the

134 correlation was not significant, but still associated to a low $P$ value $(P=0.119)$, suggesting a

135 weak relationship that was hard to detect. As more data (more locations) for 2017 were

136 unavailable, we excluded the southernmost location (L8) from that year's dataset because L8 then

137 exhibited the lowest mean barnacle size $(<0.3 \mathrm{~cm})$ for the entire dataset used for this study. This

138 modification yielded a significant correlation coefficient (Fig. 3), indicating that a positive size-

139 Chl- $a$ relationship also existed for 2017, although for a more limited geographic extent that

140 excluded the southern end of the studied coast. Chl- $a$ explained $49 \%$ of the variation in barnacle

141 size in 2014, $32 \%$ in 2015, $62 \%$ in 2016, $47 \%$ in 2017 (excluding L8), and $47 \%$ in 2018. Each

142 year, barnacle size was highest at the same two neighbouring southern locations (L6 and L7).

143 Both such locations also exhibited a higher average Chl- $a$ than the average for the other six

144 locations each year (Fig. 3).

145

DISCUSSION

Peer) reviewing PDF | (2019:01:34119:1:1:NEW 7 Mar 2019) 
146 This 5-year study along the Nova Scotia coast has revealed that the summer size of intertidal

147 barnacles recruited in the spring was positively related to the mean phytoplankton abundance for

148 the preceding months. This outcome is remarkable because the five examined correlations were

149 based on data for just eight locations (seven in 2017), a limited number that, by curbing

150 statistical power, often prevents field studies from detecting patterns in ecology. Surveying more

151 wave-exposed locations was not feasible because of safety concerns (dangerous site access or

152 lack of roads) and the need to sample all locations within a few days of difference every year.

153 Thus, the observed correlations highlight the relevance of Chl- $a$ to statistically explain the

154 alongshore variation in barnacle size. Interestingly, in four of the five studied years (2014, 2016,

1552017 -excluding L8-, and 2018), Chl- $a$ explained nearly half, or more, of such variation.

156 These results are likely explained by the fact that phytoplankton is the main food source for

157 barnacle nauplius larvae and benthic stages (Anderson, 1994; Jarrett, 2003; Gyory, Pineda \&

158 Solow, 2013). This consideration bears special relevance in light of the alongshore variation of

159 Chl- $a$ (Fig. 3), since, for the 5 years of this study, the mean annual coefficient of variation for

160 Chl- $a$ for our locations was $61 \%$. Given the temporal intra-annual resolution of the Chl- $a$ data,

161 however, it is not possible to ascertain if the purported role of phytoplankton may have differed

162 depending on the developmental stage of barnacles (from pelagic larvae to the successive benthic

163 stages until size was measured). Thus, this study should be best viewed as broad evidence

164 revealing benthic-pelagic coupling on the NW Atlantic coast using variables not previously

165 examined together for this system (Bryson, Trussell \& Ewanchuk, 2014; Scrosati \& Ellrich,

166 2018). Ultimately, this study suggests that a spatial association between phytoplankton

167 abundance and filter-feeder growth can occur on a western ocean boundary, adding to similar

168 findings reported for eastern ocean boundaries (Menge et al., 1997, 2003). 
169 A consideration about satellite Chl- $a$ data is worth making at this point. In recent years,

170 several studies on intertidal ecology that needed information on coastal phytoplankton used

171 satellite Chl- $a$ data as a proxy (Navarrete et al., 2005; Burrows et al., 2010; Arribas et al., 2014;

172 Mazzuco et al., 2015; Lara et al., 2016). Although such data are useful for coasts for which in-

173 situ phytoplankton data are unavailable (Legaard \& Thomas, 2006), the fact remains that a proxy

174 is being used. For our study, that was the only option. Because our goal was to evaluate

175 statistical relationships between summer barnacle size and average phytoplankton abundance

176 from spring to summer, having in-situ phytoplankton data would have required frequent seawater

177 samplings during those months at each of our eight locations for the five years of the study.

178 However, that was not possible for logistical reasons. Oceanographic research is continuously

179 improving the algorithms to accurately infer coastal phytoplankton abundance from satellite data

180 (Bellacicco et al., 2016; Yang et al., 2018). Thus, future studies could re-examine our hypothesis

181 as further improvements are made on that line. If the logistics to generate in-situ phytoplankton

182 data for the required spatial and temporal scales can be solved, our hypothesis could also be

183 examined using direct phytoplankton data. In any case, given the consistently positive

184 relationships between barnacle size and Chl- $a$ found for our coast, that our wave-exposed

185 locations fully face open oceanic waters, that no major rivers occur along the studied coast, that

186 human population density is very low along this coast, and that pelagic food supply enhances

187 benthic filter-feeder growth (Menge et al., 1997, 2003), it seems reasonable to expect positive

188 relationships under those improved approaches as well.

189 From the results of the present study, an emerging question of interest is what may cause

190 variation in phytoplankton abundance along the Nova Scotia coast. The intermittent upwelling

191 hypothesis (IUH; Menge \& Menge, 2013) refers to possible mechanisms. The IUH considers that 
192 frequent wind-driven upwelling would limit coastal phytoplankton abundance because upwelled

193 nutrients (necessary for phytoplankton development) would be taken offshore before nearshore

194 blooms can occur. Frequent downwelling would also limit coastal phytoplankton abundance by

195 driving nutrient-poor surface waters to the coast. Intermittent upwelling, however, would allow

196 upwelled nutrients to remain near the coast long enough for phytoplankton to bloom, thus

197 favouring the growth of intertidal filter-feeders (Menge \& Menge 2013). Wind-driven upwelling

198 has been reported for the Atlantic coast of Nova Scotia (Petrie, Topliss \& Wright, 1987; Shan et

199 al., 2016), making the IUH worth testing for this coast. In particular, a study in 1984 reported

200 coastal cooling between June and July near L6 and L7, while seawater temperature increased for

201 the same period of time near our northern locations (Petrie, Topliss \& Wright, 1987). The

202 localized upwelling on the Atlantic coast of Nova Scotia is probably intermittent, less frequent

203 and intense than on heavy-upwelling coasts like that of California. Therefore, the fact that mean

204 Chl- $a$ for L6 and L7 was higher than for the other locations every year suggests that the IUH

205 might help to understand alongshore variation in phytoplankton abundance and, ultimately,

206 intertidal barnacle growth on our coast. Alternative analytic approaches, however, have found no

207 support for the mechanisms underlying the IUH, suggesting that surf zone width and tidally

208 generated internal waves better explain changes in coastal phytoplankton abundance (Salant \&

209 Shanks, 2018; Shanks \& Morgan, 2018). At present, this topic is undergoing an active debate

210 (Menge \& Menge, 2019; Shanks \& Morgan, 2019). Whatever the causes of Chl- $a$ variation along

211 the Nova Scotia coast, it is likely that some combination of oceanographic properties is involved.

212 These properties (upwelling, surf zone width, internal waves, etc.) could change differently every

213 year along the coast, thus generating complex scenarios worth investigating from an

214 oceanographic standpoint. 
Based on data collected over five years (2014-2018) for locations spanning $415 \mathrm{~km}$ of the

217 Atlantic Canadian coast, this study reveals a persistent relationship between the summer size of

218 intertidal barnacles recruited in the preceding spring and the nearshore abundance of

219 phytoplankton (food for nauplius larvae and benthic stages of barnacles). Phytoplankton

220 abundance, measured through satellite Chl- $a$ data, explained nearly half, or more, of the

221 alongshore variation in barnacle size in four of the five studied years. These are remarkable

222 results because they were based on a relatively limited number of locations and point to the

223 relevance of pelagic food supply to explain variation in intertidal barnacle size along this western

224 ocean boundary coast.

ACKNOWLEDGEMENTS

We thank Carmen Denfeld, Willy Petzold, and Maike Willers for field assistance and two anonymous reviewers for constructive comments on an earlier version of this paper.

REFERENCES

229

Anderson DT. 1994. Barnacles. Structure, function, development, and evolution. London: Chapman \& Hall.

231 Arribas LP, Bagur M, Gutiérrez JL, Palomo MG. 2014. Matching spatial scales of variation

232 in mussel recruitment and adult densities across southwestern Atlantic rocky shores. Journal of $233 \quad$ Sea Research 95:16-21

234 Barnes H. 1956. Balanus balanoides (L.) in the Firth of Clyde: the development and annual 235 variation of the larval population, and the causative factors. Journal of Animal Ecology 25:72$236 \quad 84$ 
237 Beermann AJ, Ellrich JA, Molis M, Scrosati RA. 2013. Effects of seaweed canopies and adult

238 barnacles on barnacle recruitment: the interplay of positive and negative influences. Journal of

239 Experimental Marine Biology and Ecology 448:162-170

240 Bellacicco M, Volpe G, Colella S, Pitarch J, Santoleri R. 2016. Influence of photoacclimation

241 on the phytoplankton seasonal cycle in the Mediterranean Sea as seen by satellite. Remote

242 Sensing of Environment 184:595-604

243 Bertness MD. 1989. Intraspecific competition and facilitation in a northern acorn barnacle

244 population. Ecology 70:257-268

245 Blanchette CA, Miner CM, Raimondi PT, Lohse D, Heady KEK, Broitman BR. 2008.

246 Biogeographical patterns of rocky intertidal communities along the Pacific coast of North

247 America. Journal of Biogeography 35:1593-1607

248 Bouchard GM, Aiken RB. 2012. Latitudinal variation in the reproductive cycle and size of the

249 northern rock barnacle Semibalanus balanoides (L.) (Cirripedia, Archaeobalanidae) in the Bay

250 of Fundy. Crustaceana 85:779-787

251 Bousfield EL. 1954. The distribution and spawning seasons of barnacles on the Atlantic coast of

252 Canada. Bulletin of the National Museum of Canada 132:112-154

253 Bryson ES, Trussell GC, Ewanchuk PJ. 2014. Broad-scale geographic variation in the

254 organization of rocky intertidal communities in the Gulf of Maine. Ecological Monographs

$255 \quad 84: 579-597$

256 Burrows MT, Jenkins SR, Robb L, Harvey R. 2010. Spatial variation in size and density of

257 adult and post-settlement Semibalanus balanoides: effects of oceanographic and local

258 conditions. Marine Ecology Progress Series 398:207-219 
259 Carroll ML, Wethey DS. 1990. Predator foraging behavior: effect of a novel prey species on

260 prey selection by a marine intertidal gastropod. Journal of Experimental Marine Biology and

$261 \quad$ Ecology 139:101-117

262 Chan BKK, Morritt D, De Pirro M, Leung KMY, Williams GA. 2006. Summer mortality:

263 effects on the distribution and abundance of the acorn barnacle Tetraclita japonica on tropical

264 shores. Marine Ecology Progress Series 328:195-204

265 Cole SWB, Scrosati RA, Tam JC, Sussmann AV. 2011. Regional decoupling between NW

266 Atlantic barnacle recruit and adult density is related to changes in pelagic food supply and

267 benthic disturbance. Journal of Sea Research 65:33-37

268 Crisp DJ. 1968. Differences between North American and European populations of Balanus

269 balanoides revealed by transplantation. Fisheries Research Board of Canada 25:2633-2641

270 Drouin CA, Bourget E, Tremblay R. 2002. Larval transport processes of barnacle larvae in the

271 vicinity of the interface between two genetically different populations of Semibalanus

272 balanoides. Marine Ecology Progress Series 229:165-172

273 Dunkin SDB, Hughes RN. 1984. Behavioural components of prey-selection by dogwhelks,

274 Nucella lapillus (L.), feeding on barnacles, Semibalanus balanoides (L.), in the laboratory.

275 Journal of Experimental Marine Biology and Ecology 79:91-103

276 Ellrich JA, Scrosati RA, Molis M. 2015. Predator nonconsumptive effects on prey recruitment

277 weaken with recruit density. Ecology 96:611-616

278 Ellrich JA, Scrosati RA. 2017. Maximum water velocities in wave-exposed rocky intertidal

279 habitats from Deming Island, Atlantic coast of Nova Scotia, Canada. Available at

280 https://doi.pangaea.de/10.1594/PANGAEA.880722 (accessed 7 January 2019).

Peer] reviewing PDF | (2019:01:34119:1:1:NEW 7 Mar 2019) 
281 Emlet RB, Sadro SS. 2006. Linking stages of life history: How larval quality translates into

282 juvenile performance for an intertidal barnacle (Balanus glandula). Integrative and

283 Comparative Biology 46:334-346

284 Griffiths JR, Kadin M, Nascimento FJA, Tamelander T, Törnroos A, Bonaglia S,

The importance of benthic-pelagic coupling for marine ecosystem functioning in a changing world. Global Change Biology 23:2179-2196

Gyory J, Pineda J, Solow A. 2013. Turbidity triggers larval release by the intertidal barnacle Semibalanus balanoides. Marine Ecology Progress Series 476:141-151

Hunt HL, Scheibling RE. 2001. Patch dynamics of mussels on rocky shores: integrating process to understand pattern. Ecology 82:3213-3231

Jarrett JN. 2003. Seasonal variation in larval condition and postsettlement performance of the barnacle Semibalanus balanoides. Ecology 84:384-390

Navarrete SA, Wieters EA, Broitman BR, Castilla JC. 2005. Scales of benthic-pelagic coupling and the intensity of species interactions: from recruitment limitation to top-down control. Proceedings of the National Academy of Sciences of the United States of America 102:18046-18051

Lara C, Saldías GS, Tapia FJ, Iriarte JL, Broitman BR. 2016. Interannual variability in 300 temporal patterns of chlorophyll- $a$ and their potential influence on the supply of mussel larvae 301 to inner waters in northern Patagonia (41-44 S). Journal of Marine Systems 155:11-18 
302 Legaard KR, Thomas AC. 2006. Spatial patterns in seasonal and interannual variability of

303 chlorophyll and sea surface temperature in the California Current. Journal of Geophysical

304 Research 111:C06032

305 Mazzuco ACA, Christofoletti RA, Pineda J, Starczak VR, Ciotti AM. 2015. Temporal

306 variation in intertidal community recruitment and its relationships to physical forcings,

307 chlorophyll- $a$ concentration, and sea surface temperature. Marine Biology 162:1705-1725

308 Menge BA. 1976. Organization of the New England rocky intertidal community: role of

309 predation, competition, and environmental heterogeneity. Ecological Monographs 46:355-393

310 Menge BA, Daley BA, Wheeler PA, Dahlhoff E, Sanford E, Strub PT. 1997. Benthic-pelagic

311 links and rocky intertidal communities: bottom-up effects or top-down control? Proceedings of

312 the National Academy of Sciences of the United States of America 94:14530-14535

313 Menge BA, Lubchenco J, Bracken MES, Chan F, Foley MM, Freidenburg TL, Gaines SD,

314 Hudson G, Krenz C, Leslie H, Menge DNL, Russell R, Webster MS. 2003. Coastal

315 oceanography sets the pace of rocky intertidal community dynamics. Proceedings of the

316 National Academy of Sciences of the United States of America 100:12229-12234

317 Menge BA, Menge DNL. 2013. Dynamics of coastal meta-ecosystems: the intermittent

318 upwelling hypothesis and a test in rocky intertidal regions. Ecological Monographs 83:283-310

319 Menge BA, Menge DNL. 2019. Testing the intermittent upwelling hypothesis: comment.

320 Ecology 100:e2476

321 NASA. 2019a. National Aeronautics and Space Administration. OceanColor data. Available at

322 https://oceandata.sci.gsfc.nasa.gov/MODIS-Aqua/Mapped/Daily/4km/chlor_a (accessed 4

323 March 2019) 
324 NASA. 2019b. National Aeronautics and Space Administration. SeaDAS. Available at

325 https://seadas.gsfc.nasa.gov (accessed 4 March 2019)

326 Petrie B, Topliss BJ, Wright DG. 1987. Coastal upwelling and eddy development off Nova

327 Scotia. Journal of Geophysical Research 29:12979-12991

328 Quinn GP, Keough MJ. 2002. Experimental design and data analyses for biologists.

329 Cambridge: Cambridge University Press.

330 R Core Team. 2018. $R$ : a language and environment for statistical computing. Vienna: $\mathrm{R}$

331 Foundation for Statistical Computing.

332 Salant CD, Shanks AL. 2018. Surf-zone hydrodynamics alter phytoplankton subsidies affecting

333 reproductive output and growth of tidal filter-feeders. Ecology 99:1878-1889

334 Scrosati RA, Ellrich JA. 2016. A 12-year record of intertidal barnacle recruitment in Atlantic

335 Canada (2005-2016): relationships with sea surface temperature and phytoplankton abundance.

336 PeerJ 4:e2623

337 Scrosati RA, Ellrich JA. 2018. Benthic-pelagic coupling and bottom-up forcing in rocky

338 intertidal communities along the Atlantic Canadian coast. Ecosphere 9:e02229

339 Scrosati R, Heaven C. 2007. Spatial trends in community richness, diversity, and evenness

340 across rocky intertidal environmental stress gradients in eastern Canada. Marine Ecology

341 Progress Series 342:1-14

342 Shan S, Sheng J, Ohashi K, Dever M. 2016. Assessing the performance of a multi-nested

343 ocean circulation model using satellite remote sensing and in-situ observations. Satellite

344 Oceanography and Meteorology 1:39-59 
345 Shanks AL, Morgan SG. 2018. Testing the intermittent upwelling hypothesis: upwelling,

346 downwelling, and subsidies to the intertidal zone. Ecological Monographs 88:22-35

347 Shanks AL, Morgan SG. 2019. Testing the intermittent upwelling hypothesis: reply. Ecology

$348 \quad$ 100:e02516

349 Tam JC, Scrosati RA. 2011. Mussel and dogwhelk distribution along the northwest Atlantic

350 coast: testing predictions derived from the abundant-centre model. Journal of Biogeography

$351 \quad 38: 1536-1545$

352 Tide-Forecast. 2019. Tide times and tide charts worldwide. Available at

353 http://www.tide-forecast.com (accessed 4 March 2019)

354 Yang MM, Ishizaka J, Goes JI, Gomes HR, Maúre ER, Hayashi M, Katano T, Fujii N,

355 Saitoh K, Mine T, Yamashita H, Fujii N, Mizuno A. 2018. Improved MODIS-Aqua

356 chlorophyll- $a$ retrievals in the turbid semi-enclosed Ariake Bay, Japan. Remote Sensing

$357 \quad \mathbf{1 0}: 1335$ 
359 Figure legends

360 Fig. 1. Map indicating the eight wave-exposed locations studied along the Atlantic coast of Nova 361 Scotia, Canada.

362 Fig. 2. Example of barnacle size differences between locations: (A) L1 and (B) L6. The frame 363 bordering each photo belongs to the sampling quadrat. One full side of the quadrat $(10 \mathrm{~cm})$ is 364 shown at the top of both pictures. The photos were taken by R. A. Scrosati in August 2018.

365 Fig. 3. Relationships between coastal phytoplankton abundance (chlorophyll- $a$ concentration) 366 and intertidal barnacle size in (A) 2014, (B) 2015, (C) 2016, (D) 2017, and (E) 2018. The 367 correlation and functional relationship shown for 2017 were calculated without including L8 368 (see Results for rationale); the data point for L8 is nonetheless shown in this figure simply for 369 visual reference.

370 


\section{Table 1 (on next page)}

Information on locations

Names and coordinates of the eight wave-exposed intertidal locations examined for this study and coordinates of the centre of the $4-\mathrm{km}-\mathrm{x}-4-\mathrm{km}$ cells from which Chl-a data were extracted. 
1 Table 1. Names and coordinates of the eight wave-exposed intertidal locations examined for this 2 study and coordinates of the centre of the 4-km-x-4-km cells from which Chl- $a$ data were 3 extracted.

4

\begin{tabular}{llcc}
\hline Location code & Location name & Location coordinates & Cell centre coordinates \\
\hline L1 & Glasgow Head & $45.3203,-60.9592$ & $45.3125,-60.9791$ \\
L2 & Deming Island & $45.2121,-61.1738$ & $45.2292,-61.1875$ \\
L3 & Tor Bay Provincial Park & $45.1823,-61.3553$ & $45.1875,-61.3542$ \\
L4 & Sober Island & $44.8223,-62.4573$ & $44.8125,-62.4375$ \\
L5 & Duck Reef & $44.4913,-63.5270$ & $44.4797,-63.5208$ \\
L6 & Western Head & $43.9896,-64.6607$ & $43.9797,-64.6458$ \\
L7 & West Point & $43.6533,-65.1309$ & $43.6458,-65.1458$ \\
L8 & Baccaro Point & $43.4496,-65.4697$ & $43.4375,-65.4792$ \\
\hline
\end{tabular}




\section{Table 2 (on next page)}

Survey dates and sample sizes

Dates on which the quadrats were photographed. The number of available quadrats with barnacle size data is provided in parenthesis. 
1 Table 2. Dates on which the quadrats were photographed. The number of available quadrats with 2 barnacle size data is provided in parenthesis.

3

\begin{tabular}{|c|c|c|c|c|c|}
\hline Location & 2014 & 2015 & 2016 & 2017 & 2018 \\
\hline $\mathrm{L} 1$ & 17 August (8) & 4 September (17) & 22 August (8) & 16 August (12) & 13 August (8) \\
\hline $\mathrm{L} 2$ & 9 August (8) & 28 August (7) & 22 August (8) & 25 August (8) & 13 August (8) \\
\hline L3 & 10 August (4) & 28 August (11) & 25 August (3) & 28 August (8) & 13 August (7) \\
\hline L4 & 13 August (7) & 2 September (16) & 27 August (4) & 19 August (8) & 14 August (8) \\
\hline L5 & 12 August (7) & 1 September (21) & 21 August (7) & 22 August (8) & 11 August (8) \\
\hline L6 & 12 August (8) & 31 August (20) & 20 August (8) & 21 August (8) & 10 August (8) \\
\hline L7 & 11 August (2) & 30 August (14) & 19 August (7) & 18 August (7) & 10 August (7) \\
\hline L8 & 11 August (6) & 29 August (8) & 19 August (3) & 18 August (5) & 10 August (7) \\
\hline
\end{tabular}


Figure 1

Map of the studied locations.

Map indicating the eight wave-exposed locations studied along the Atlantic coast of Nova Scotia, Canada.

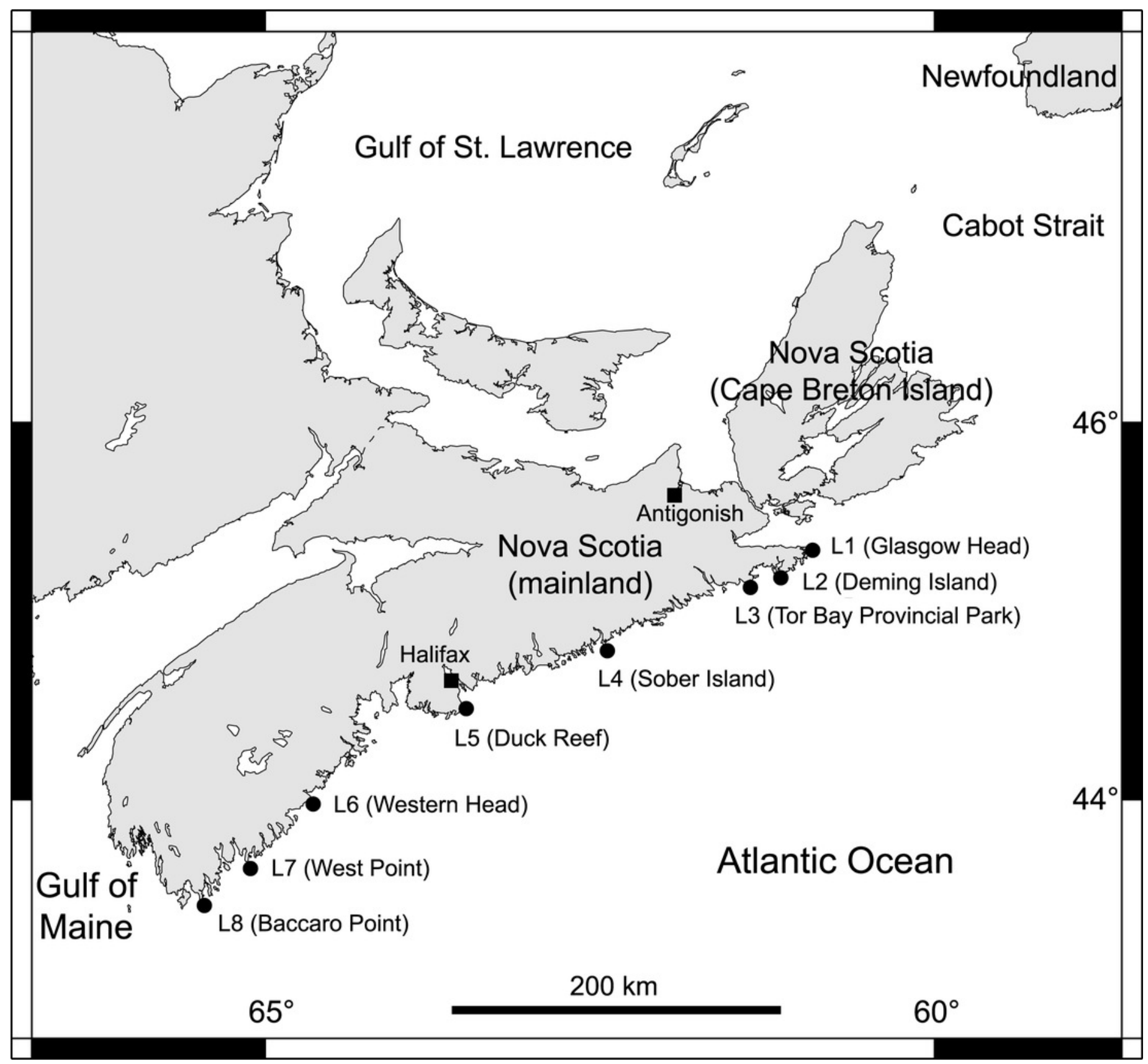




\section{Figure 2}

Barnacle size.

Example of barnacle size differences between locations: (A) L1 and (B) L6. The frame bordering each photo belongs to the sampling quadrat. One full side of the quadrat $(10 \mathrm{~cm})$ is shown at the top of both pictures. The photos were taken by Ricardo A. Scrosati in August 2018. 

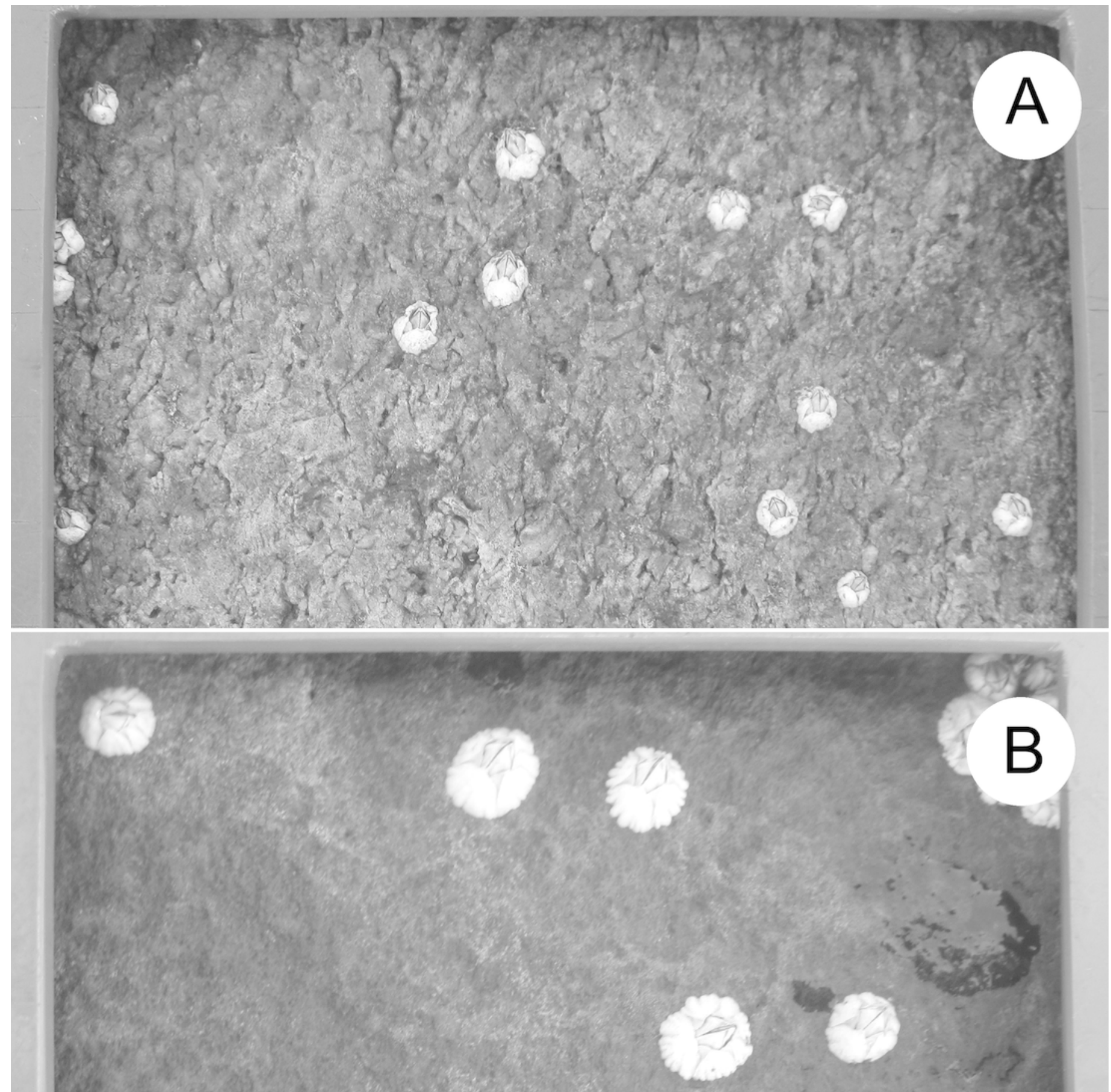


\section{Figure 3}

Relationships between coastal phytoplankton abundance (chlorophyll-a concentration) and intertidal barnacle size.

Relationships between coastal phytoplankton abundance (chlorophyll-a concentration) and intertidal barnacle size in (A) 2014, (B) 2015, (C) 2016, (D) 2017, and (E) 2018. The correlation and functional relationship shown for 2017 were calculated without including L8 (see Results for rationale); the data point for $L 8$ is nonetheless shown in this figure simply for visual reference. 

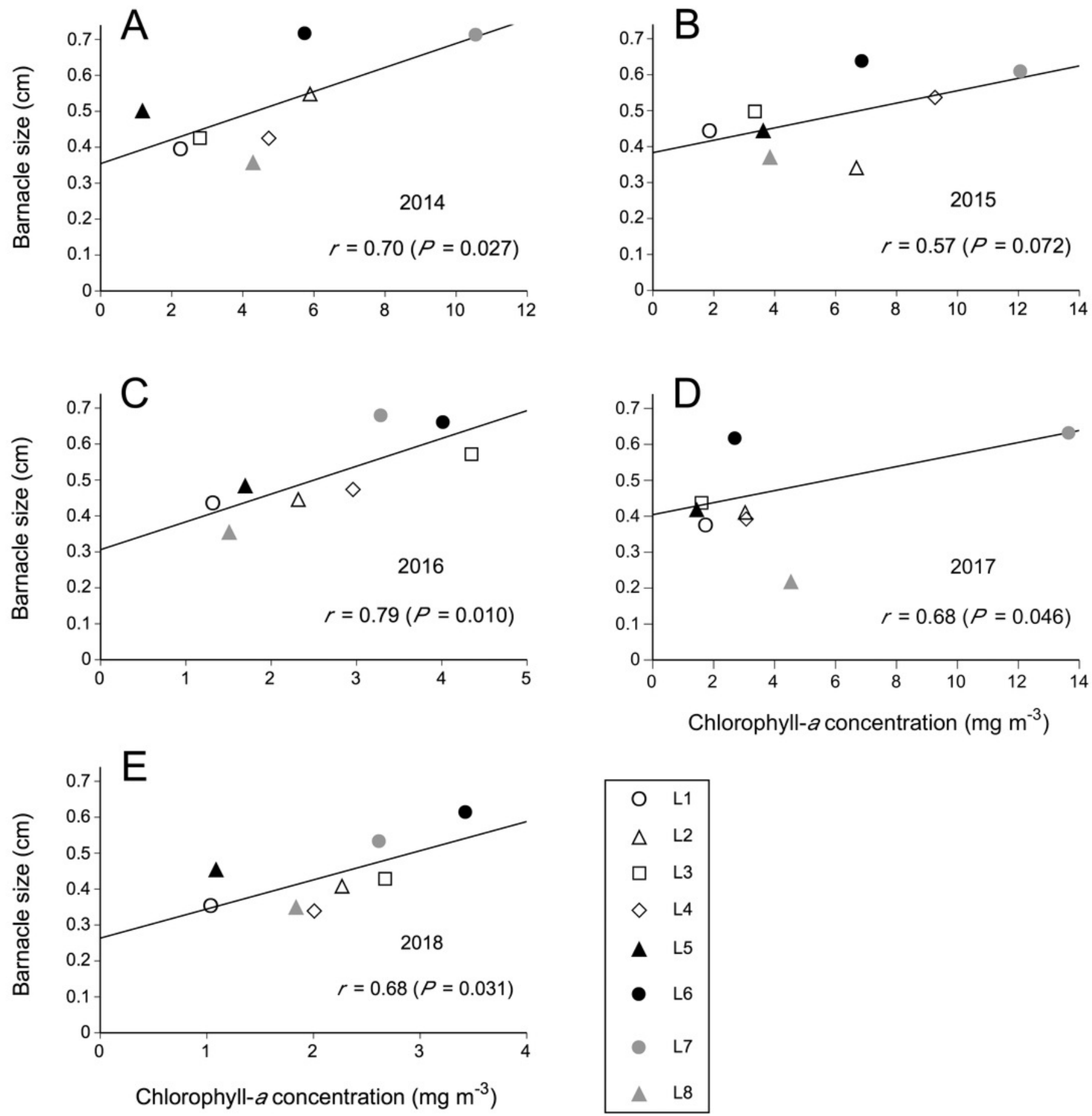

\begin{tabular}{|cc|}
\hline $\mathrm{O}$ & $\mathrm{L} 1$ \\
$\Delta$ & $\mathrm{L} 2$ \\
$\square$ & $\mathrm{L} 3$ \\
$\diamond$ & $\mathrm{L} 4$ \\
$\Delta$ & $\mathrm{L} 5$ \\
$\bullet$ & $\mathrm{L} 6$ \\
$\bullet$ & $\mathrm{L} 7$ \\
$\Delta$ & $\mathrm{L} 8$ \\
\hline
\end{tabular}

